\title{
Penile cancer: Is there an epidemiological role for smoking and sexual behaviour?
}

\author{
DAN HELLBERG, JACK VALENTIN, TORE EKLUND, STAFFAN NILSSON
}

\begin{abstract}
A retrospective study was carried out to determine whether penile cancer, like cervical cancer, was associated with smoking and sexual behaviour. Altogether 244 men with penile cancer and 232 matched controls completed a questionnaire by post or telephone. Data on marital state, socioeconomic group, occupation, history of phimosis and balanitis, sexual behaviour, and smoking were obtained. The results of statistical analyses confirmed that phimosis and balanitis were risk factors for penile cancer, but there was no epidemiological evidence for it being a sexually transmitted disease. Smoking was a risk factor with a dose-response relation and remained associated with penile cancer even after adjustment for confounding factors.

Penile cancer is associated with smoking independently of phimosis; treatment of phimosis alone does not remove the risk caused by smoking.
\end{abstract}

\section{Introduction}

Cancer of the penis is a serious health problem in many parts of the world. In the Western World the incidence of penile cancer varies from 0.5 to 1.5 per 100000 men. In many parts of the world, however, it is the most common male cancer with an incidence of 2 to 5 per 100000 , constituting-for example, $12 \%$ to $22 \%$ of all male cancers in China, Uganda, and Puerto Rico. ${ }^{1}$ The incidence is extremely low in Israel and Moslem countries, where neonatal circumcision or circumcision during childhood is practised: only nine cases of penile cancer in Jewish men circumcised neonatally have been reported world wide, ${ }^{2}$ but a higher incidence has been reported in Moslems, who practise circumcision at 5-10 years of age. $^{3}$

Circumcision has been known to be a negative risk factor since the beginning of this century. ${ }^{4}$ Known risk factors are phimosis and balanitis: phimosis has been reported in $50 \%$ to $98 \%$ of patients with penile cancer, and chronic suppuration and a history of balanitis are also very common. ${ }^{48}$

Smoking in women has been accepted as a genuine risk factor for cervical neoplasia. ${ }^{10} \mathrm{~W}$ inkelstein hypothesised that smoking causes squamoepithelial cancer not only in parts of the body in contact with smoke (lung, larynx) but also far from where it makes contact (urinary bladder, cervix) by means of the circulatory system. ${ }^{11}$ This hypothesis may apply to penile cancer, which in $98 \%$ of cases is squamoepithelial.

Human papillomavirus has recently been implicated as a causal agent in penile cancer, ${ }^{12-16}$ which suggests that this cancer may be a sexually transmitted disease, ${ }^{17}$ with its female counterpart being

\footnotetext{
Department of Obstetrics and Gynaecology, Uppsala University, Falu Hospital, S-791 82 Falun, Sweden

DAN HELLBERG, MD

STAFFAN NILSSON, MD, PHD

National Institute of Radiation Protection, Stockholm

JACK VALENTIN, PHD

Department of Urology, Falu Hospital

TORE EKLUND, MD

Correspondence to: Dr Hellberg.
}

cervical cancer. ${ }^{18-20}$ If penile cancer were sexually transmitted this would be reflected epidemiologically by measuring sexual behaviour (low age at first intercourse and many sexual partners), as for cervical cancer.

\section{Subjects and methods}

In Sweden an average of 50 men a year are diagnosed as having cancer of the penis, giving an incidehce of 1.4 per $100000 .{ }^{21}$ All cases of cancer are registered at the National Cancer Registry, which in 1958-80 registered 1064 new cases. As the median age of onset in Sweden is 65 to 69 years ${ }^{21}$ a large proportion of these patients were dead when we started this study. The population studied was all living men under 80 with cancer of the penis, who numbered 299. According to the regulations of the National Cancer Registry, the doctor who diagnosed or treated each patient must give his or her written permission to allow an interview with the patient. We traced the doctors for 247 patients, and they all gave their permission. Three patients were excluded from the study because of serious brain damage due to cerebrovascular disease.

For each patient we selected a control subject from the Swedish population registry. The controls were matched for age and geographical area. Fifteen of the 247 controls were excluded because they had brain damage due to cerebrovascular disease, had recently died, or had moved abroad, thus giving a control group of 232 men.

All 476 men in both groups, most of whom were aged 60-80 years, were sent a questionnaire. This included questions about marriage, occupation, smoking habits, use of snuff, history of phimosis and balanitis, age at first intercourse, and the number of sexual partners during their life. The men were particularly asked not to answer questions on subjects about which they were not absolutely sure to avoid biasing the results. The questionnaire was coded, and only we had access to the code, which guaranteed total anonymity and meant that no identification numbers would be registered when the results were statistically analysed. In cases in which there was no reply to the questionnaire a maximum of two reminders were sent. On the fourth occasion patients were sent a letter asking permission for an interview by telephone; those who agreed were subsequently interviewed by telephone by one of us.

All information was entered into a computer. Initial significance tests were done with $\chi^{2}$ or Student's $t$ tests as appropriate. To assess the simultaneous effect of all likely explanatory variables we analysed multiway frequency tables. As patients were matched with controls in the design of this study we performed analyses with a logistic approach for matched data. ${ }^{22}$ Unmatched log linear analyses were also used, whose results were similar to those in the logistic analyses.

\section{Results}

The questionnaire was answered by $381(80 \%)$ men, and another 43 agreed to be interviewed by telephone, giving a total response rate of 424 out of $476(89 \%)$. A slightly higher proportion of patients $(91 \%, 223)$ than controls $(87 \%, 201)$ agreed to be interviewed. Not all subjects were able to answer all the questions. The most difficult to answer were those concerning sexual history. Of the 424 who responded, $22(5 \%)$ did not know the number of sexual partners and $34(8 \%)$ had forgotten how old they were when they had first had sexual intercourse. Those who could not answer either or both of these questions were equally distributed among patients and controls.

Penile cancer was not associated with a particular occupation nor was there any significant difference in its distribution among different socioeconomic groups. ${ }^{23}$ The incidence of penile cancer tended to be higher among lower classes; a comparison of classes 1 and 2 (lower) with classes 3-5 (higher) gave a $\chi^{2}$ value of $3.73(p=0.05)$. People in classes 1 and 2 also tended to smoke more often so that when socioeconomic group was controlled for smoking the significance of socioeconomic group vanished.

An equal proportion (88\%) of men in the two groups were or had been married (197 patients, 175 for controls). There was no difference in age at 
first intercourse, with a median age at first intercourse of 18 for both groups and an equal distribution in all age groups (table I). As men with phimosis might have had a different sexual history from other men age at first intercourse was controlled for phimosis. This did not change the findings.

Only seven men with penile cancer and five controls said that they had never had intercourse with a woman (table II). On average, both groups of men had had intercourse with six to 10 women during their lives. There was no statistical difference between patients and controls, and this remained so when the number of sexual partners was controlled for phimosis.

TABLE I-Age at first intercourse among men with penile cancer compared with that among matched controls. Values are numbers of men (percentages)

\begin{tabular}{lccc}
\hline $\begin{array}{c}\text { Age at first } \\
\text { intercourse } \\
\text { (years) }\end{array}$ & $\begin{array}{c}\text { Men with } \\
\text { penile cancer } \\
(\mathrm{n}=206)\end{array}$ & $\begin{array}{c}\text { Controls } \\
(\mathrm{n}=184)\end{array}$ & $\begin{array}{c}\text { Relative } \\
\text { risk }\end{array}$ \\
\hline$<15$ & $3(2)$ & $9(5)$ & $0 \cdot 30$ \\
$15-16$ & $34(17)$ & $24(13)$ & $1 \cdot 27$ \\
$17-18$ & $60(29)$ & $55(30)$ & 0.97 \\
$>18$ & $102(50)$ & $91(50)$ & $1 \cdot 00$ \\
Never & $7(3)$ & $5(3)$ & $1 \cdot 25$ \\
\hline
\end{tabular}

Contingency $\chi^{2}=0.03, \mathrm{df}=4, \mathrm{p}=0.8$.

TABLE II-Numbers of lifetime sexual partmers among men with penile cancer compared with those among matched controls. Values are numbers of men (percentages)

\begin{tabular}{lccc}
\hline $\begin{array}{l}\text { No of } \\
\text { sexual } \\
\text { partners }\end{array}$ & $\begin{array}{c}\text { Men with } \\
\text { penile cancer } \\
(\mathrm{n}=212)\end{array}$ & $\begin{array}{c}\text { Controls } \\
(\mathrm{n}=190)\end{array}$ & $\begin{array}{c}\text { Relative risk } \\
(95 \% \text { confidence } \\
\text { interval })\end{array}$ \\
\hline 0 & $7(3)$ & $5(3)$ & \\
1 & $43(20)$ & $39(21)$ & 1.00 \\
2 & $28(13)$ & $19(10)$ & $1.33(0.64$ to $2 \cdot 76)$ \\
$3-5$ & $41(19)$ & $49(26)$ & $0.75(0.41$ to 1.38$)$ \\
$6-10$ & $50(24)$ & $34(18)$ & $1.33(0.72$ to 2.46$)$ \\
$\geqslant 11$ & $43(20)$ & $44(23)$ & $0.88(0.48$ to 1.62$)$ \\
\hline
\end{tabular}

Contingency $\chi^{2}=0 \cdot 1, \mathrm{df}=5, \mathrm{p}=0 \cdot 75$.

As would be expected, there was a much greater prevalence of phimosis among men with cancer of the penis (table III). The relative risk of having penile cancer among men with phimosis was $64 \cdot 6$, which was a highly significant excess risk. The large numbers of men with a history of one or more episodes of balanitis was also significant among those with penile cancer (table IV); the relative risk was $9 \cdot 49$ for men who had experienced one or more epsodes of balanitis. As balanitis may be difficult to remember (the beginnings of penile cancer could be misinterpreted as balanitis by patients) those who stated that they had suffered from balanitis more than once were

TABLE III-Distribution of phimosis among men with penile cancer compared with that among matched controls. Values are numbers of men (percentages)

\begin{tabular}{lccl}
\hline & $\begin{array}{c}\text { Men with } \\
\text { penile cancer } \\
(\mathrm{n}=217)\end{array}$ & $\begin{array}{c}\text { Controls } \\
(\mathrm{n}=197)\end{array}$ & $\begin{array}{c}\text { Relative risk } \\
\left(\begin{array}{l}9 \% \% \text { confidence } \\
\text { interval })\end{array}\right.\end{array}$ \\
\hline $\begin{array}{l}\text { No phimosis } \\
\text { Phimosis }\end{array}$ & $\begin{array}{c}53(24) \\
164(76)\end{array}$ & $\begin{array}{c}188(95) \\
9(5)\end{array}$ & $\begin{array}{l}1 \cdot 0 \\
64 \cdot 6(30 \text { to } 135)\end{array}$ \\
\hline
\end{tabular}

Contingency $\chi^{2}=213 \cdot 5, \mathrm{df}=1, \mathrm{p}<0.0001$.

TABLE IV-Distribution of episodes of balanitis among men with penile cancer compared with those among matched controls. Values are numbers of men (percentages)

\begin{tabular}{lccc}
\hline & $\begin{array}{c}\text { Men with } \\
\text { penile cancer } \\
(\mathrm{n}=207)\end{array}$ & $\begin{array}{c}\text { Controls } \\
(\mathrm{n}=193)\end{array}$ & $\begin{array}{c}\text { Relative risk } \\
(95 \% \text { confidence } \\
\text { interval })\end{array}$ \\
\hline No balanitis & $115(56)$ & $178(92)$ & 1.0 \\
Balanitis & $92(45)$ & $15(8)$ & $9 \cdot 5(5 \cdot 2$ to $17 \cdot 2)$ \\
$\quad 1$ episode & $50(24)$ & $4(2)$ & $19 \cdot 3(6.8$ to $55 \cdot 0)$ \\
$\geqslant 2$ episodes & $42(20)$ & $11(6)$ & $5.9(2.9$ to 11.9$)$ \\
\hline
\end{tabular}

Contingency $\chi^{2}=67 \cdot 4, \mathrm{df}=3, p<0 \cdot 0001$. analysed separately, but balanitis remained a strong risk factor for penile cancer. Balanitis could also be secondary to phimosis and therefore phimosis was controlled for in one analysis. The relative risk with balanitis then decreased to $5 \cdot 22$ but was still significant $(p<0.001)$.

Table V shows the distribution of smoking in the two groups. Smoking had a significant effect on the prevalence of penile cancer even when the amount of smoking was not considered. When smokers were grouped according to the number of cigarettes smoked a day we saw a clear doseresponse relation, with smokers of more than 10 cigarettes a day having a significantly higher risk than light smokers (one to 10 cigarettes a day) $\left(\chi^{2}=\right.$ $5.43, p=0.02$ ). The relative risk of having penile cancer for smokers of more than 10 cigarettes a day was $1 \cdot 88(95 \%$ confidence interval $1 \cdot 10$ to $3 \cdot 19)$ when compared with light smokers and $2 \cdot 22$ when compared with non-smokers.

TABLE V-Distribution of smoking habits among men with penile cancer compared with that among matched controls. Values are numbers of men (percentages)

\begin{tabular}{lccl}
\hline Smoking habit & $\begin{array}{c}\text { Men with } \\
\text { penile cancer } \\
(\mathrm{n}=233)\end{array}$ & $\begin{array}{c}\text { Controls } \\
(\mathrm{n}=200)\end{array}$ & $\begin{array}{c}\text { Relative risk } \\
(95 \% \text { confidence } \\
\text { interval })\end{array}$ \\
\hline Non-smoker & $67(30)$ & $82(41)$ & $1 \cdot 00$ \\
Ex-smoker & $28(13)$ & $20(10)$ & $1 \cdot 71(0.88$ to 3.30$)$ \\
Smoker: & $128(57)$ & $98(49)$ & $1.61(1.08$ to $2 \cdot 41)$ \\
$\quad 1$-10 cigarettes/day & $57(26)$ & $59(30)$ & $1 \cdot 18(0.72$ to 1.92$)$ \\
$>10$ cigarettes/day & $11(5)$ & $7(4)$ & $2.22(1.34$ to 3.69$)$ \\
\hline
\end{tabular}

Contingency $\chi^{2}=4 \cdot 89, \mathrm{df}=3, p<0 \cdot 05$, for comparison of smokers with non-smokers.

Table $V$ shows that ex-smokers had a higher risk of having penile cancer than light smokers. This might have been because ex-smokers were not grouped according to the number of cigarettes that they had consumed a day. Had this been done ex-smokers would have been expected to have a relative risk closer to that for smokers. Thus we found a clear dose-response relation between smoking and penile cancer, but no effect of duration of smoking. This might have been because most men in this study had smoked for a very long time ( $88 \%$ for more than five years). We also asked about taking snuff; we found no difference in the proportions using it $(6 \%)$.

We identified three risk factors, phimosis, balanitis, and smoking, which, despite having been statistically controlled for single possible confounding factors, remained significantly associated with penile cancer. Our initial analyses also showed an association between phimosis and balanitis and phimosis and smoking, but not balanitis and smoking. We then did a logistic regression analysis, adjusting simultaneously for smoking, balanitis, and phimosis, to give the genuine risk for each of these factors. For light smokers the risk was 0.98 (95\% confidence interval 0.68 to 1.42 ); for smokers smoking 11 or more cigarettes a day $1.53(1.00$ to 2.35$)$; for men with a history of phimosis $57.4(14.1$ to 233$)$; and for those with a history of balanitis $2 \cdot 44(1 \cdot 03-5 \cdot 78)$. Despite the adjustment for possible confounding effects of both phimosis and balanitis smoking remained a risk factor for penile cancer: the relative risk in smokers of more than 10 cigarettes a day was $1 \cdot 53$, but the lower limit of the confidence interval was $1 \cdot 00$.

\section{Discussion}

We interpret our results as supporting the hypothesis that smoking is a risk factor for penile cancer. The association between smoking and penile cancer was direct, related to the dose, and independent of other known risk factors, which suggests that smoking is a genuine causal factor. By comparison with the cervix, where high concentrations of nicotine and cotinine have been found in cervical mucus, ${ }^{10}$ tobacco products could become concentrated in smegma, making it carcinogenic, especially in men with phimosis. Castonguay et al showed that in rats nitrosamines specific to tobacco were not only excreted by the kidneys but also concentrated in the preputial glands. ${ }^{24}$

An alternative interpretation is possible, however, because we studied only living men: theoretically smoking could have prolonged the lives of men with penile cancer, thus explaining the larger proportion of smokers in this group. This interpretation, however, seems unlikely: there is no other non-hormone dependent cancer in which smoking is known to prolong life, and smokers are known to die earlier than non-smokers. The prevalence of smoking would be expected to be higher in the group of men who had died of penile 
cancer, but the same would also apply to a control group of dead men, so no bias would be expected for smoking.

There is no evidence that different forms of penile cancer exist with different aetiologies. In this study of living men the average year of birth was 1918 and that for all cases in Sweden from 1958 to 1980 was 1904 . As penile cancer generally has a good prognosis, with up to $90 \%$ of patients surviving five years, ${ }^{25}$ age may be the main factor that differs between the population studied here and a cumulative population of patients with penile cancer.

This study also confirms earlier known risk factors for penile cancer (phimosis and balanitis). Phimosis seems to be a genuine risk factor, which probably occurs through the retention of smegma because smegma is not retained in the group at negative risk-that is, those men who were circumcised during childhood. The increasing incidence of early circumcision and better hygienic standards may account for the fall in the incidence of penile cancer in the United States. ${ }^{26}$ In tests of carcinogenicity of smegma smegma from horses (which have a high incidence of penile cancer) was found to be carcinogenic in mice, ${ }^{27}$ whereas human smegma was carcinogenic in mice in one study ${ }^{28}$ but not in another ${ }^{29}$; in this latter study, however, only four mice were tested so the results are not conclusive.

We did not confirm the hypothesis that penile cancer is a sexually transmitted disease. This may be because of bias in recalling sexual history, although we might expect recall to be more detailed among patients than controls because they are more likely to try to remember exactly their sexual experiences. In addition, we instructed both patients and controls to leave questions unanswered if there was any shadow of doubt about their answers. It therefore seems plausible that penile cancer is not sexually transmitted.

If so the theory that human papillomavirus is an aetiological agent in penile as well as cervical cancer may be difficult to defend. In $90 \%$ of cases of cervical cancer deoxyribonucleic acid from human papillomavirus, mainly types 16 and 18 , has been isolated from cancer cells, ${ }^{30}$ but it has been isolated from only 35 out of $85(41 \%)$ cases of penile cancer tested. ${ }^{12-16}$ Rather than causing penile cancer human papillomavirus type 16 seems to cause cancer in situ (Bowen's disease) ${ }^{1431}$ or bowenoid papulosis. ${ }^{31}$ This may explain why cervical cancer is transmitted sexually and penile cancer is not. Of course, another type of human papillomavirus with other modes of transmission than sexual might cause penile cancer; the numbers of types of human papillomavirus isolated is steadily increasing and there are now more than $40 .{ }^{30}$ Another explanation may be that infection with the virus is so prevalent in a normal population that measures of sexual behaviour do not reflect its transmission ( $\mathrm{H}$ zur Hausen, personal communication).

In summary, the results of this study suggest that another cancer, penile cancer, may be caused by smoking. This association between penile cancer and smoking can be explained biologically and is independent of phimosis; treatment of phimosis alone could not be expected to rule out the risk caused by smoking. We could not, however, show that penile cancer was a sexually transmitted disease.

We thank Ann-Sofi Axelsson for excellent secretarial help and the Research Council of Dalarna for supporting this study.

\section{References}

1 Persky L. Epidemiology of cancer of the penis. Recent Results Cancer Res 1977;60:97-109. 2 Boczko S, Freed S. Penile carcinoma in circumcised males. NY State f Med 1979;39:1903-4. 3 Tan RE. Observations on frequency of carcinoma of the penis at Macassar and its environs (South Celebes). $\mathcal{F}$ Urol 1963;89:704-5.

4 Barney JD. Epithelioma of the penis. An analysis of one hundred cases. Ann Surg 1907;46: $890-914$

5 Wolbarst AL. Circumcision and penile cancer. Lancet 1932;i:150-3.

6 Dean AL. Epithelioma of the penis. $\mathcal{F}$ Urol 1935;33:252-83.

7 Jensen MS. Cancer of the penis in Denmark 1942-1962 (511 cases). Dan Med Bull 1977;24:66-72. 8 Muir CS, Nectoux J. Epidemiology of cancer of the testis and penis. Nat Cancer Inst Monogr 1979;53:157-64

9 Hellberg D, Valentin J, Nilsson S. Smoking as risk factor in cervical neoplasia. Lancet 1983;ii: 1497

10 Sasson IM, Hellberg D, Haley NJ, Hoffman D, Nilsson S, Wynder EL. Cigarette smoking and neoplasia of the uterine cervix: smoke constituents in cervical mucus. $N$ Engl f Med neoplasia of the

11 Winkelstein W. Smoking and cancer of the uterine cervix: hypothesis. Am $\mathcal{f}$ Epidemiol 1977:106:257-9.

12 Dürst $M$, Gissman L, Ikenberg H, zur Hausen H. A papillomavirus DNA from a cervical carcinoma and its prevalence in cancer biopsy samples from different geographic regions. Proc Natl Acad Sci USA 1983;80:3812-5.

13 Boshart M, Gissman L, Ikenberg H, Kleinheinz A, Scheurlen W, zur Haussen H. A new type of papillomavirus DNA, its presence in genital cancer biopsies and in cell lines derived from cervical cancer. $E M B O f$ 1984;3:1151-7.

14 Dürst M, Kleinheinz A, Hotz M, Gissman L. The physical state of human papillomavirus type 16 in benign and malignant genital tumours. $f$ Gen Virol 1985;66:1515-22.

$15 \mathrm{McCance}$ DJ, Kalache A, Ashdown K, et al. Human papillomavirus types 16 and 18 in carcinomas of the penis from Brazil. Int $\mathcal{f}$ Cancer 1986;37:55-9.

16 Villa LL, Lopes A. Human papillomavirus DNA sequences in penile carcinomas in Brazil. Int $\mathcal{F}$ Cancer 1986;37:853-5.

17 Peters RK, Mack TM, Bernstein L. Parallels in the epidemiology of selected anogenital carcinomas. Joumal of the National Cancer Institute 1984;72:609-15.

18 Wynder EL, Cornfield J, Schroff PD, Doraiswami KR. A study of environmental factors in carcinoma of the cervix. Am f Obstet Gynecol 1954;68:1016-52.

19 Rotkin ID. Etiology and epidemiology of cervical cancer. In: Dallenbach-Hellwegg G, ed. Current topics in pathology. Berlin: Springer Verlag, 1981:81-109.

20 Skegg DCG, Corwin PA, Paul C, Doll R. Importance of the male factor in cancer of the cervix. Lancet 1982;ii:581-3.

21 National Board of Health and Welfare. Cancer incidence in Sweden. Stockholm: NBHW, 1980.

22 Lubin JA. A computer program for the analysis of matched case-control studies. Comput Biomed Res 1981;14:138-43.

23 Central Bureau of Statistics. Socioekonomisk indelning. Stockholm: CBS, 1982:4

24 Castonguay A, Tjälve $\mathrm{H}$, Hecht SS. Tissue distribution of the tobacco-specific carcinogen 4-(methylnitrosamino)-1-(3-pyridyl)-1-butanone and its metabolites in F344 rats. Cancer Res 1983;43:630-8.

25 Ekström T, Edsmyr F. Cancer of the penis. A clinical study of 229 cases. Acta Chir Scand 1958;115:25-45.

26 Cowdry EV. Cancer in man. New York: Appleton-Century-Crofts, 1968:220-4.

27 Plaut A, Kohn-Speyer AC. The carcinogenic action of smegma. Science 1947;105:391-2.

28 Reddy DG, Baruah IKSM. Carcinogenic action of human smegma. Archives of Pathology 1963;75:86-92.

29 Pratt-Thomas HR, Heins HC, Latham E, Dennis EJ, McIvere FA. The carcinogenic effect of human smegma: an experimental study. Cancer 1956;9:671-80.

30 zur Hausen H. Genital papillomavirus infections. Prog Med Virol 1985;32:15-21.

31 Ikenberg H, Gissman L, Gross G, Grussendorf-Conen E-I. Human papillomavirus type-16related DNA in genital Bowen's disease and in bowenoid papulosis. Int f Cancer 1983;32:563-5.

(Accepted 15 September 1987)

\section{YEARS AGO}

The habit of reading sanguinary recitals bristling with the details of the most hideous crimes is one which can hardly fail to produce an unhealthy moral tone in those addicted thereto. Instances are not wanting in which the perusal of the legendary feats of Dick Turpin and his congeners has paved the way to the commission of crime by young and inexperienced persons, to whom crime had been described with a halo of heroism and courage, in which, as a matter of fact, it is generally wanting. The Birmingham coroner recently held an inquest on a young woman, the circumstances of whose death open up another point of view in the harmful results which may accrue from inconsiderate tampering with the emotions. The young woman in question had been to the Grand Theatre to witness the performance of a piece called "The World Against Her." She was very much affected by what she saw, and took the earliest possible opportunity of putting an end to an existence which she had just seen depicted in such gloomy colours. No doubt suicide is a comparatively rare sequel to a theatrical performance; but most of us are probably familiar with the depression, occasionally of a very marked character, which may follow a more than usually lugubrious novel or play. Such an effect is, fortunately, ephemeral as a general rule, and affects one less acutely than the troubles of daily life. There are moments, however, when the mind becomes more amenable to such enervating influences, and there are persons who are constitutionally prone to experience violent emotional disturbance, and on whose nervous system too dramatic a recital may produce a really damaging shock. It is more particularly in individuals whose imagination is undisciplined and has not been made subservient to the reasoning faculties, that the most harmful effects are to be witnessed; and, under certain circumstances, the psychical depression may, as in the present instance, give rise to a suicidal impulse. In women and children the absence of due control over the emotions is frequently due to the unhealthy development which results from the ordinary system of female education. Violent emotional disturbances, when frequently repeated, leave a mark on the mind akin to the wrinkles which follow their expression on the features, and disfigure one like the other. Too great care cannot be shown in shielding the young and the emotionally weak from such influences, the effect of which may be injurious and lasting. (British Medical fournal 1887;i:1229.) 